\title{
Corporate Cash Holdings and Financial Crisis: Evidence from Jordan
}

\author{
Asma'a Al-Amarneh ${ }^{1}$ \\ ${ }^{1}$ Finance and Banking Department, Applied Science Private University, Jordan \\ Correspondence: Asma'a Al-Amarneh, Finance and Banking Department, Applied Science Private University, \\ Jordan. Tel: 962-795-513-798. E-mail: A_alamarneh@asu,edu.jo or asmaa.amarneh@yahoo.com
}

Received: March 4, 2015

doi:10.5539/ibr.v8n5p212
Accepted: March 20, 2015

Online Published: April 25, 2015

URL: http://dx.doi.org/10.5539/ibr.v8n5p212

\begin{abstract}
The focal point of this study is to investigate whether the Jordanian companies hold more cash after the financial crisis compared to before the financial crisis and which theories can explain these cash holdings. This work addresses the following questions: 1) what determine the corporate cash holdings in Jordan in normal time and during crisis. 2) How do the financial crises affect the policy of cash holding in the Jordanian firms?

This study investigates the effect of capital expenditure, profitability, cash flows, investment (growth) opportunities, leverage, and ability to access capital markets, dividend's payment and liquid assets substitutes. The study use data from 47 industrial companies listed at Amman Stock Exchange (ASE) during the period 2001 to 2011, with total 517 firm-year observations.

The study time period was divided into four sub periods to assess the changes in cash holdings during each period. Panel regression was applied to examine the study model; also ANOVA test was used to test the differences in means for each sub period. Our results show that; Jordanian companies tend to increase their cash holdings because of financial crisis by increasing debt, decreasing investment activity and reducing payouts to shareholders. Moreover, the study show a different patterns in cash holdings during the pre crisis period and the post-crisis period, also there is a different patterns in cash holdings during the base period and the pre-crisis period. In addition, the main theories that explain the changes in cash holdings for the Jordanian companies were trade off theory and the pecking order theory. Generally speaking, our results support the trade off theory. The precautionary motive founded to be the most important motives for the Jordanian firms to hold cash. Generally, Cash flow, liquid assets substitutes, degree of financial leverage and dividend payment policy are the most important determinants of corporate cash holdings in Jordan.
\end{abstract}

Keywords: corporate cash holdings, trade off theory, pecking order theory, free cash flow theory, financial crisis

\section{Introduction}

Firms across the globe have exposed to substantial changes after the global financial crisis. Some companies were forced to close up, but some survived. During financial crisis the external financing became more expensive and difficult to obtain. So, firms try to increase their cash holdings to avoid the liquidity crunch. It is clear that, firms tend to apply a conservative financing policy and implement a low investment policy over the short term period after the financial crisis begins, which means rational companies must save more money. The focal point of this study is to investigate how Jordanian firms would effectively manage their cash holdings during the financial crisis, in order to avoid or to postpone bankruptcy.

In literature, there are three main theories that can explain the corporate cash holdings. First theory is the trade off theory which claims that; when firms decide the level of cash it should hold it should take into account the cost and benefit of holding cash, the second theory is the pecking order theory by Myers and Majlue (1984), they classify the main resources of finance can be used by any firm and rank the cash as a primary source of finance followed by debt and leave the financing by equity as a last source. The last theory is the agency theory by Jensen (1986) who suggests that managers prefer to accumulate cash to increase the amount of assets under their control instead of paying it out to shareholders.

Also, firms have several motivations to hold cash. Mainly, cash can be used to make payment instead of liquidating assets calling for transaction motives (Baumol, 1952), so firms can reduce transaction cost by holdings more cash. Miller-Orr model (1966), while the precautionary motive refers to holding cash for safety reasons and the precautionary motive refers to hold cash for safety reasons and to hedge future cash shortfalls 
(Keynes, 1936; Opler et al., 1999). According to Besley and Brigham (2005) corporations hold cash for speculative motives to take advantage of any good investment opportunities that may arise.

Clearly, holding appropriate reserve of cash can help firms to maintain a healthy financial position and reduce the chance of bankruptcy during financial crisis. Moreover, for any firm, it is essential to hold an appropriate level of cash and cash equivalent to smooth daily operations in the firm. Many previous research found that the appropriate level of cash can be determined by a list of variables such as cash flow management, investment management, dividend and capital requirements (Opler et al., 1999; Afza \& Adnan, 2007).

This study investigates how Jordanian firms manage cash holdings, in general and during the financial crises, and then predict the effect of financial crisis on corporate cash holdings theories and motivations.

The paper consists of the following sections: section (2) for literature review, section (3) for data collection and methodology, the empirical results presented in section (4), finally, section (5) concludes the paper.

\section{Literature Review}

In financial literature there are few basic accepted models concerning the corporate cash holdings. Early in 1952 Baumol created the first model that treat the cash as an inventory like any commodity (inventory model), he argued that rational financial managers should take care of the amount of cash they should hold in such away they keep the benefit from holding this amount is greater than its cost. In 1966 Miller-Orr expanded the inventory model suggested by Baumol and takes into account the random nature of cash expenditure and receipts. Specifically, he analyzed the movement of money from cash balance to investment account and found that this movement was random in time and size (production model).

Wealth theoretical approach is another widely accepted approach to cash management suggested by Meltzer; who found in (1963) that cash balance is affected by changes in interest rate in the market and the size of total assets held by the firm (its wealth), also the choice of holding a certain amount of cash is constrained by the yield on this type of wealth as another type of wealthy assets.

In their capital structure theory; Modigliani and Miller suggest that firms do not need to reserve cash because they work in perfect capital market. But in real world firms operate in imperfect markets where there are transaction cost, taxes bankruptcy and agency cost; all these factors make the determination of cash holdings an important question that firms should answer in order to survive. They argued that the firms decided what amount of cash to hold by understanding he mix of its needs and requirements.

Cossin and Hricko (2004) found that financial managers need to understand the determinants of corporate cash holdings to avoid holding of excessive cash and to allow optimal timing of investment.

The model developed by Almeida et al. (2004) relates the financial constraints to firm's propensity to save cash. They found that cash flow sensitivity of financially constrained firms is increased during crisis while unconstrained firms sensitivity to cash flow is unaffected by business cycle.

Elkinawy et al. (2007) investigates the effect of Mexican crisis of 1994-1995 and the Brazilian crisis of 1999 on corporate cash holdings using a sample of Latin America firms. They found that each crisis has a different effect on the determinants of cash holdings and firm value. During the Mexican crisis; larger firms increase their cash holdings, while cross listed firms increase their holdings of cash during the Brazilian crisis. Their study suggests that; illiquidity may be more severe during crisis, but agency costs are also an important factor.

Gao and Yun (2009) show that, if firm has no enough liquidity as a result of financial crisis, it will forgo some investment opportunities and experience a decline in profitability to save more cash, while firms with enough liquidity will maintain their business activities at the pre-crisis level.

Duchine et al. (2009) examined the effect of the financial crisis on corporate investment and find that firms reduce their investments significantly following the start of the financial crisis.

Campelo et al. (2011) find that after 2008 crisis firms increase their holdings and decrease their debt. In addition, the combination of global financial crisis makes liquidity management more challenging.

Kahle and Stulz (2011) find that net equity issuance deceases during the crisis, along with an increase in cash holding, the evidence of which suggests of an increase in risk as a result of the crisis. Furthermore, with more debt, firms cannot accumulate excess cash over time, due to the payment to debt holders (Jensen, 1986), which implies a negative relation between cash holdings and leverage. The evidence suggests that cash holdings are negatively related to leverage and equity issuance.

Song and Lee (2012) investigate the effect of Asian financial crisis on corporate cash holdings by analyzing 
32,174 firm-years observations representing 5,059 unique firms from 8 East Asian countries. They found that firms became more conservative in investing and cash holdings policies after the crisis. Also, their study found that increase in cash holdings explained by firms' demand function for cash, and changes in firm characteristics have no effect on cash holdings.

In their paper, Pinkowitz et al. (2013) show that American firms hold cash after the crisis more than firms with similar characteristics in the late 1990s. They call cash holdings that cannot be explained by cash holding patterns from the late 1990s abnormal cash holdings. The difference was $1.93 \%$ of assets indicating an increase in abnormal cash holdings throughout the sample period for different reasons. The increase in abnormal cash holdings of U.S firms is concentrated among highly profitable firms.

In summary, the literature review indicates that firms' increase in cash holdings is mostly explained by changes in firm characteristics and changes in their demand function for cash as a result of bad times.

Concerning Jordanian firms, Al-amarneh (2013) found that liquid assets substitutes, cash flow, growth opportunities and financial leverage were important predictors of corporate cash holdings. In addition, Jordanian firms hold cash mainly for precautionary and transaction motivations.

This study contributes to the literature on the main determinants of corporate cash holdings by focuses on Jordanian industrial firms and how these firms determine their cash holdings in normal times and during the financial crisis? The findings of this study may useful to policy maker, as well as capital market participants, to understand the liquidity issues and consequences in the crisis.

\section{Method}

\subsection{Methodology}

To achieve the main aim of this study; a panel data regression model was used to investigate the main determinants of corporate cash holdings; our model makes cash holdings depend on variables that proxy for the motives to hold cash that have been analyzed in the literature.

The study covers periods from 2001-2011 which sub divided into four sub periods. The first period is 2001-2003, which we call the base period. We call the second period, 2004-2006, the pre-crisis period. The crisis period covers 2007 and 2009 .Finally; the post-crisis period is 2010-2011. The motivation for these periods is straightforward. We want to understand the post-crisis holdings and whether they are different from pre-crisis holdings. Further, we want to assess whether the change in cash holdings from the pre-crisis period to the post crisis period has similar patterns to change in cash holdings from the base period to the pre-crisis period.

\subsection{Sample Selection}

For the purpose of this study, a sample of publicly traded industrial firms has been used. The sample includes companies that appeared on ASE at any time during the sample period (2001-2011). Some of these firms were excluded because the needed information is not available for the specific time period of the study. The final sample results in a 517 firm-year observations with 47 distinct industrial firms.

\subsection{Variable Measurement}

This study focuses on the firms' characteristics as a determinant of corporate cash holding in normal time and during crisis. Table (1) list all variables selected to be responsible for changing in cash holdings for the selected Jordanian firms in the four sub periods.

Table 1. Variable definition

\begin{tabular}{|c|c|c|c|}
\hline Variable & Full Name & Description & Predicting \\
\hline Cashratio & Cash ratio & Cash and cash equivalents / Net Assets. & Cash holdings \\
\hline Capexp & Capital Expenditure & The annual change in fixed assets added to depreciation. & Investment Activity \\
\hline Cashflow & Cash flow & (net profit After tax + Depreciation)/ Net Assets. & Business operations \\
\hline Leverage & Leverage Ratio & Total debt / Net assets & Financial Leverage \\
\hline NWC & Net working capital & (Current assets- cash and cash equivalents - current liability ) / net assets. & Liquid Asset Substitutes \\
\hline ROA & Return On Assets & Net income / net assets. & Profitability \\
\hline Size & Firm size & Natural logarithm of Net assets & Financial constraints \\
\hline Divyield & Dividend yield & Dividends paid / stock price & Financial constraints \\
\hline Tobinq & Tobins' Q & (Book value of debt + Market value of equity) / book value of assets. & Long-term growth \\
\hline
\end{tabular}


We add the financial crisis dummy to classify the four time periods of the study (Lian et.al, 2011). In this study the net assets represent all assets except the cash balance and near cash assets. (Opler et al., 1999), also the study is aimed to test the following regression model:

$$
\begin{gathered}
\text { CASH }_{i, t}=\alpha_{0}+\alpha_{1} \text { CF }_{i, t}+\alpha_{2} \operatorname{CapExp}_{i, t}+\alpha_{3} \text { NWC }_{i, t}+\alpha_{4} L V R G_{i, t}+\alpha_{5} \text { SIZE }_{i, t}+\alpha_{6} \text { DIVY }_{i, t}+\alpha_{7} \text { TOBINQ }_{i, t} \\
+\alpha_{8} \text { ROA }_{\mathrm{i}, t}+\alpha_{9} \text { Financial Crisis Dummy }_{i, t}
\end{gathered}
$$

Where the $\mu_{\mathrm{i}, \mathrm{t}}$ represents the error term of the model.

\section{Result}

\subsection{Descriptive Statistics}

Figures in Table 2 shows the cash holdings during the different periods we classify in our study. On average the Jordanian firms hold about (9.6\%) of net assets as cash. In the EMU area companies average cash ratio has been $15 \%, 18 \%$ in the US and worldwide round 9\% (Opler et al., 1999; Dittmar, 2003; Ferreire \& Vilela, 2004; Schwetzler \& Reimund, 2004); which means that Jordanian firms hold cash within the worldwide range.

Table 2. Descriptive statistics for cash holdings ratio (2001-2011)

\begin{tabular}{cccccc}
\hline Time Periods & Mean & Median & Max & Min. & Std. Dev. \\
\hline Base period & 0.141969 & 0.051431 & 1.073943 & -0.020272 & 0.219892 \\
Pre crisis period & 0.065221 & 0.028199 & 0.586247 & -0.288892 & 0.107479 \\
Crisis period & 0.092342 & 0.014443 & 1.971990 & -0.392946 & 0.250245 \\
Post crisis period & 0.093449 & 0.016735 & 1.827130 & -0.256466 & 0.280057 \\
All & 0.096216 & 0.028040 & 1.971990 & -0.392946 & 0.208936 \\
\hline
\end{tabular}

Figure 1 shows that; during base period the level of cash holdings was over the average value (14\%), for the pre crisis period the cash holdings decreased on average to $(6.5 \%)$, then start to increase during the financial crisis period and after. The peak value was in (2009) during the financial crisis period.

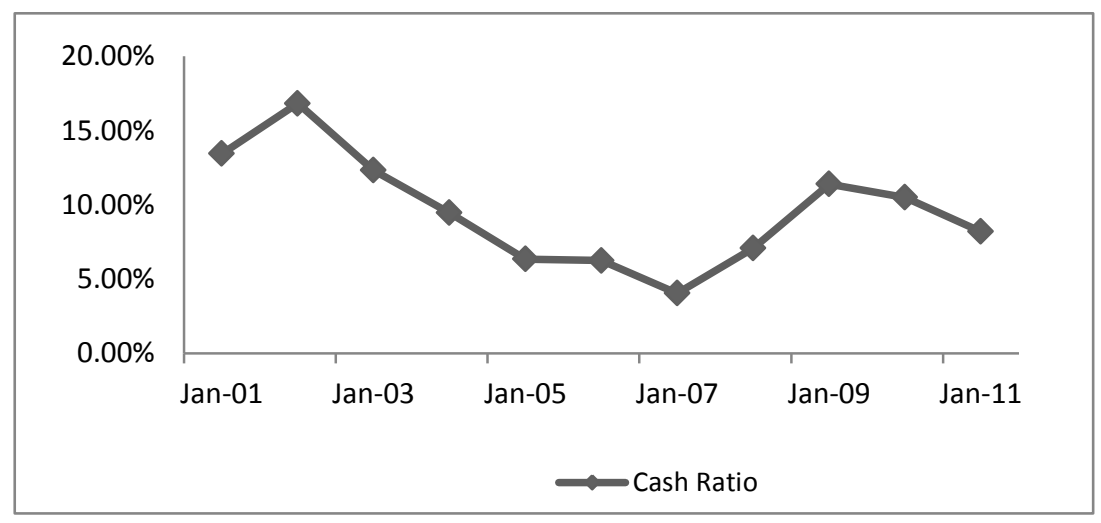

Figure 1. Time trend of cash holdings during the period 2001-2011

Figure 2 shows the comparison between small firms and large firms in the mean of cash holdings from 2001 to 2011. It is clear that, during the financial crisis period large firms hold less cash than small firms. During the financial crisis period large firms hold less cash than small firms, and the gap between small and large firms became more widen during the financial crisis, while the large firms were holding more cash before the financial crisis. These results indicate that small firms became more risky during crisis and save more cash for transaction purposes (Miller \& Orr, 1966), and precautionary purposes (Keynes, 1936). 


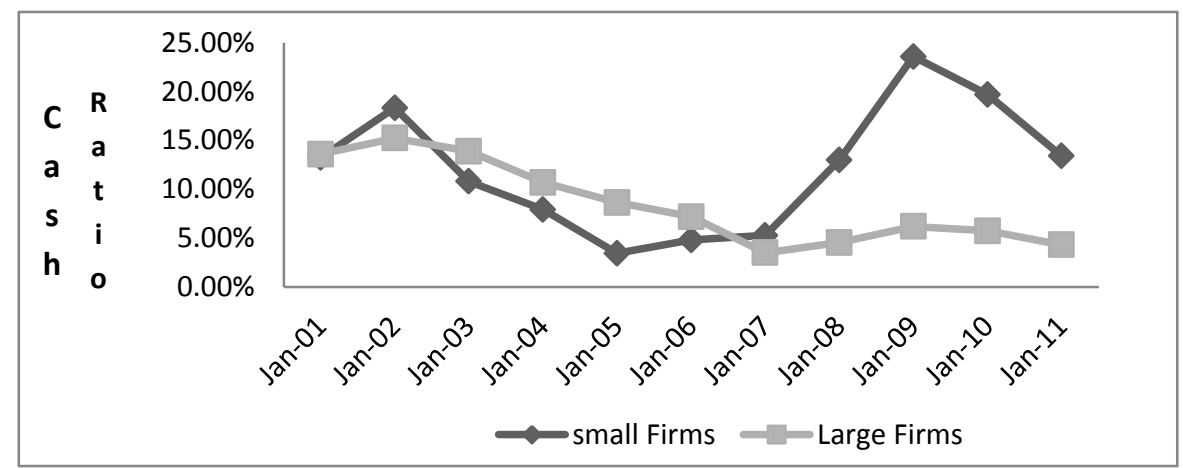

Figure 2. Small and Large firms cash Holdings during the period 2001 till 2011

Note. Firms are divided into two groups; firms with total assets greater than average are defined as "Large Firms", and others are defined as "Small Firms".

Figure 3 depicts annual cash ratio movement with the main factors affecting the corporate cash holdings, while Figure 4 depicts the annual cash ratio with long term growth measured by Tobin's Q.

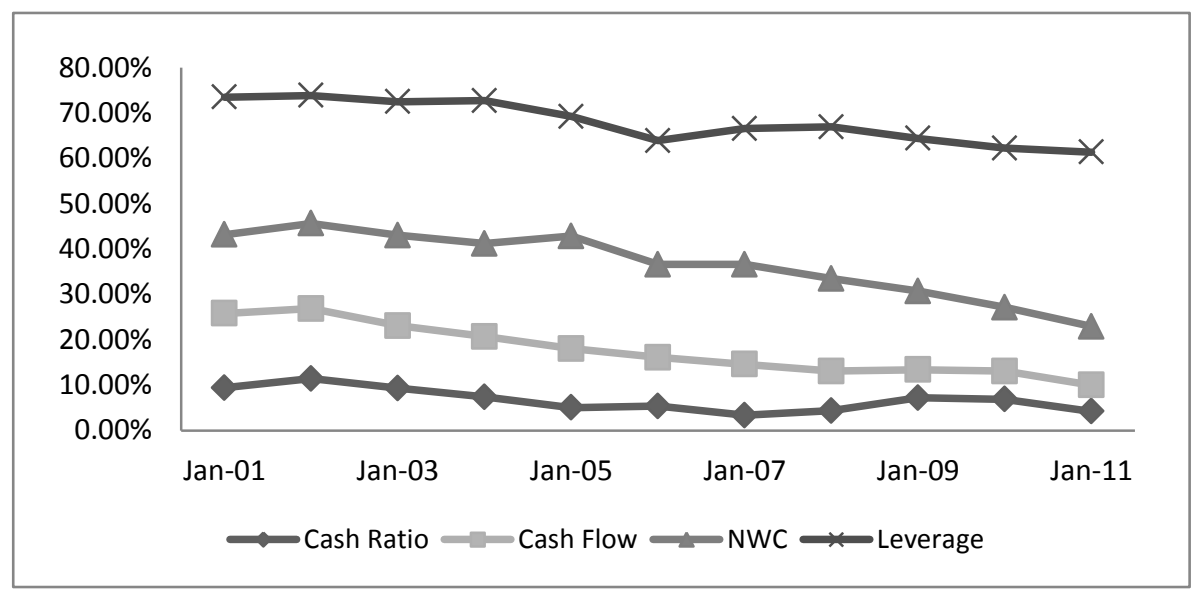

Figure 3. Time trend of average cash holding, cash flow, NWC, and leverage during 2001-2011

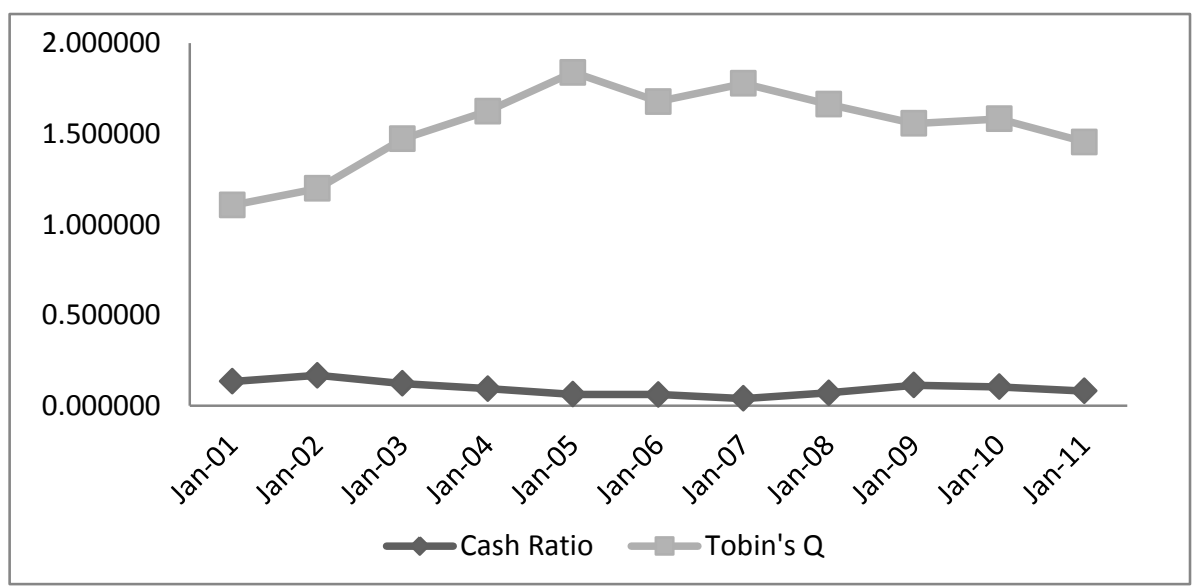

Figure 4. Time trend of average cash holdings and Tobin's Q during 2001-2011

Table 3 shows the descriptive statistics of the dependent and independent variables for the whole time period of the study (2001-2011). 
Table 3. Descriptive statistics for key variables (2001-2011)

\begin{tabular}{lcccc}
\hline Variable & Minimum & Maximum & Mean & Median \\
\hline Cash & -0.392946 & 1.971990 & 0.096216 & 0.028040 \\
Capital Expenditure & -0.74694 & .968262 & 0.062103 & -0.25707 \\
Cash flow & -0.586195 & 1.709837 & 0.110025 & 0.078578 \\
NWC & -1.194597 & 1.206346 & 0.212573 & 0.063542 \\
Leverage & 0.016764 & 1.794765 & 0.305363 & 0.269485 \\
Firm Size (in millions) & 0.677924 & $1,008.000$ & 42.58 & 11.38 \\
Dividend Yield & 0.000 & 0.353846 & 0.028597 & 0.00500 \\
Tobin's Q & 0.385549 & 8.070894 & 1.452223 & 1.189960 \\
Return On Assets (ROA) & -63.68000 & 43.94000 & 2.624574 & 3.950000 \\
\hline
\end{tabular}

Note. The same results were founded by (Al-Amarneh, 2013).

On average Jordanian firm holds $9.6 \%$ of its net assets in cash, which represent approximately 4.3 million Jordanian Dinar, a relatively small amount. According to our data, the average net asset is about JD 45.0 million. The mean leverage was $30.5 \%$, with average profitability measured by return on asset of $2.62 \%$. on average, the Jordanian firms have a Tobin's Q ratio with value greater than one which indicates that these firms have a good investment opportunities, also their stocks provide shareholders with $2.9 \%$ as a dividend for each one JD of price, on the other hand, the cash flow generated from the main business of these firms around $11 \%$ of net assets. Also Jordanian industrial companies' net working capital represent about $21.3 \%$ of its net assets and capital expenditure percentage change was around $6.2 \%$ annually.

The correlation between suggested variables was tested and the correlation coefficients presented on Table 4 .

Table 4. Correlation matrix

\begin{tabular}{|c|c|c|c|c|c|c|c|c|c|}
\hline & Cash Ratio & Cash Flow & NWC & Leverage & SIZE & DIVYIELD & TOBINQ & ROA & CAPEXP \\
\hline \multirow[t]{2}{*}{ CASHRATIO } & 1.000000 & & & & & & & & \\
\hline & ----- & & & & & & & & \\
\hline \multirow[t]{2}{*}{ CASHFLOW } & 0.260701 & 1.000000 & & & & & & & \\
\hline & $(0.0000)$ & ----- & & & & & & & \\
\hline \multirow[t]{2}{*}{ NWC } & 0.091414 & 0.107193 & 1.000000 & & & & & & \\
\hline & $(0.0381)$ & $(0.0149)$ & ----- & & & & & & \\
\hline \multirow[t]{2}{*}{ LEVERAGE } & -0.409000 & -0.209118 & -0.488737 & 1.000000 & & & & & \\
\hline & $(0.0000)$ & $(0.0000)$ & $(0.0000)$ & ----- & & & & & \\
\hline \multirow[t]{2}{*}{ SIZE } & 0.059590 & 0.212971 & -0.204940 & 0.263369 & 1.000000 & & & & \\
\hline & $(0.1769)$ & $(0.0000)$ & $(0.0000)$ & $(0.0000)$ & ----- & & & & \\
\hline \multirow[t]{2}{*}{ DIVYIELD } & 0.284128 & 0.494735 & 0.189489 & -0.209270 & 0.193693 & 1.000000 & & & \\
\hline & $(0.0000)$ & $(0.0000)$ & $(0.0000)$ & $(0.0000)$ & $(0.0000)$ & ----- & & & \\
\hline \multirow[t]{2}{*}{ TOBINQ } & 0.279423 & 0.292673 & -0.133798 & -0.091419 & 0.002503 & 0.071668 & 1.000000 & & \\
\hline & $(0.0000)$ & $(0.0000)$ & $(0.0023)$ & $(0.0381)$ & $(0.9548)$ & $(0.1043)$ & ----- & & \\
\hline \multirow[t]{2}{*}{ ROA } & 0.357939 & 0.742801 & 0.137303 & -0.237314 & 0.314421 & 0.588411 & 0.371682 & 1.000000 & \\
\hline & $(0.0000)$ & $(0.0000)$ & $(0.0018)$ & $(0.0000)$ & $(0.0000)$ & $(0.0000)$ & $(0.0000)$ & ----- & \\
\hline \multirow[t]{2}{*}{ CAPEXP } & 0.055620 & 0.127761 & -0.123337 & 0.054632 & 0.170691 & 0.039923 & 0.244776 & 0.217124 & 1.000000 \\
\hline & $(0.2076)$ & $(0.0037)$ & $(0.0051)$ & $(0.2158)$ & $(0.0001)$ & $(0.3659)$ & $(0.0000)$ & $(0.0000)$ & ----- \\
\hline
\end{tabular}

The correlation matrix shows that, corporate cash holdings is positively correlated with the cash flow, NWC, Dividend yield, Tobin's Q and ROA, and negatively correlated with degree of leverage. 


\subsection{Empirical Results}

\subsubsection{ANOVA Test}

We test for the equality of means of cash ratio during the four sub-periods classified in our study. According to ANOVA test result appears in Table 5 the Jordanian firms hold less cash in normal times (6.5\%) and increase their cash holdings during bad times $(9.2 \%)$.

Table 5. ANOVA test results for dependent variable: cash holdings

\begin{tabular}{lcccc}
\hline Method & & df & Value & Probability \\
\hline Anova F-test & & $(3,513)$ & 3.706643 & 0.0117 \\
Welch F-test* & $(3,202.802)$ & 5.023534 & 0.0022 \\
Category Statistics & & & \\
CRISISDUMMY & Count & Mean & Std. Dev. & Std. Err. of Mean \\
Base period & 141 & 0.141969 & 0.219892 & 0.018518 \\
Pre crisis period & 188 & 0.065221 & 0.107479 & 0.007839 \\
Crisis period & 94 & 0.092342 & 0.250245 & 0.025811 \\
Post crisis period & 94 & 0.093449 & 0.280057 & 0.028886 \\
All & $\mathbf{5 1 7}$ & $\mathbf{0 . 0 9 6 2 1 6}$ & $\mathbf{0 . 2 0 8 9 3 6}$ & $\mathbf{0 . 0 0 9 1 8 9}$ \\
\hline
\end{tabular}

As a result of increasing cash holdings, the firm liquidity management policy should be affected also the investment decision, payout policy, and all financial affairs of the firm. To investigate these changes, we find the differences in means for all key predictors of cash holdings used in this study during the four sub periods and then we test for significance of these differences using ANOVA test, the results presented in Table 6.

Table 6. Anova test results for IN-dependent variables

\begin{tabular}{lcccc}
\hline Time Periods & \multicolumn{2}{c}{ Mean of Variable } & DivYield & Leverage \\
\hline Panel A: & CapExp & Cash flow & 0.035871 & 0.293346 \\
Base period & -0.015923 & 0.152287 & 0.026344 & 0.287769 \\
Pre crisis period & 0.096678 & 0.120753 & 0.025021 & 0.335588 \\
Crisis period & 0.130121 & 0.074551 & 0.019987 & 0.367951 \\
Post crisis period & 0.038711 & 0.059912 & 0.027382 & 0.312563 \\
All & 0.06151 & 0.109891 & 3.416064 & 3.533862 \\
Anova F-test & 1.751451 & 4.234086 & 0.0173 & 0.0147 \\
Probability & 0.1555 & 0.0057 & Size & Tobins'Q \\
Panel B: & $\mathbf{N W C}$ & $\mathbf{R O A}$ & 16.19273 & 1.117658 \\
Base period & 0.187049 & 3.536184 & 16.42024 & 1.664966 \\
Pre crisis period & 0.214668 & 4.776835 & 16.60554 & 1.517919 \\
Crisis period & 0.188654 & 0.715054 & 16.50549 & 1.425590 \\
Post crisis period & 0.134612 & -1.198830 & 16.40738 & 1.445441 \\
All & 0.189668 & 2.6245774 & 2.055040 & 9.618000 \\
\hline \multicolumn{1}{c}{ Anova F-test } & 2.828054 & 8.578013 & 0.1053 & 0.0000 \\
\hline \multicolumn{1}{c}{ Probability } & 0.0380 & 0.000 & & \\
\hline
\end{tabular}

The results show that all firm characteristics' show significant differences during the four sub periods except capital expenditure. The annual percentage change in firms' capital expenditure before financial crisis was (9.6\%) compare to $(3.8 \%)$ after the financial crisis, for the same periods the cash holdings was $(6.5 \%)$ before crisis and increased to (9.3\%) after the crisis but these differences in means are not significant as shown in table 
(5). This finding suggests that, Jordanian firms increase cash holdings by decreasing investment activity after the financial crisis. The mean of cash flow was (12\%) of net assets before crisis and sharply decreased by almost half to $(5.99 \% \approx 6 \%)$ after the crisis indicating that firms' operations affected badly by financial crisis and the operating cash flow was not the source of accumulating cash after the crisis.

The dividend yield mean was (2.6\%) before crisis decreased to (1.9\%) after crisis time, indicating that firms build up cash after the crisis by reducing payouts to shareholders.

In addition, firms extend more debt during crisis time $(33 \%)$ and after crisis $(36.79 \% \approx 36.8 \%)$ more than pre-crisis $(28.77 \%)$ which is not consistent with the pecking order theory, suggesting the firms should depend on its internal sources of liquidity before going outside and seek for external liquidity sources. So, we can argue that increasing of cash after the crisis is driven by increasing debt. The growth opportunity decrease from (tobins' $\mathrm{Q}=1.66$ ) before crisis to (1.52) during crisis and (1.42) after crisis, also profitability decrease from (4.7\%) before crisis to $(0.7 \% 0)$ during crisis and $(-1.19 \%)$ after crisis. It is clear that, the Jordanian firms' growth opportunities decreased during and after crisis accordingly, the profitability level decreased. In spite of poor investment opportunities, firms holds more cash during and after crisis which is consistent with the agency theory which suggests entrenched manager tend to retain cash than pay it out. Moreover, the net working capital percentage of net assets decreased from (22\%) before crisis to (18\%) during crisis time and (13.46\%) after crisis. Low level of liquid substitutes during crisis leads to high level of cash holdings as trade-off theory predicts.

\subsubsection{Regression Analysis}

Panel data regression was applied for random effect, first time for the whole sample period to determine which factors may affect the corporate cash holdings in general and then applied for each time period classified in the study to investigate how firms manage cash during each period. The results in the first column of Table 7 indicate that financial crisis has positively affected the corporate desire for holding more cash; which means; Jordanian cash holdings tend to increase during the financial crisis as a result of increasing risk so firm can stay liquid. Results show that cash holdings are positively affected by the profitability figures. Our study show a week but significant effect while Elkinaway and Stater (2007) found a strong effect, which is consistent with pecking order theory which suggests that profitability firms use its internal resources as a primary source of fund. Large firms with more liquid asset substitute tend to hold less cash because it can converts its liquid assets other than cash into cash as trade-off theory suggests.

Table 7. Results of panel random effect regression

\begin{tabular}{|c|c|c|c|c|c|}
\hline Sample sub-periods & Whole period & Base Period & Pre-crisis & During -crisis & Post-crisis \\
\hline Variable & & & Coefficient & & \\
\hline CASH(-1) & $0.794202 *$ & $0.649540 *$ & $0.533418^{*}$ & $0.908740^{*}$ & $0.894058^{*}$ \\
\hline Crisis Dummy & $0.031194 * *$ & Crisis dummy $=0$ & Crisis dummy $=1$ & Crisis dummy $=2$ & Crisis dummy $=3$ \\
\hline Capital Expenditure & $-0.016905 * *$ & -0.097396 & -0.006552 & -0.010500 & 0.0047944 \\
\hline Cash Flow & -0.010160 & 0.003200 & 0.009779 & -0.004666 & -0.034819 \\
\hline Leverage & $-0.116512^{*}$ & $-0.329573 * *$ & $-0.070992 * *$ & $-0.198164 * *$ & $0.058951 * *$ \\
\hline DIVY & $0.217927 * * *$ & 0.503508 & $0.300849 * *$ & -0.034636 & 0.568151 \\
\hline NWC & $-0.141020^{*}$ & $-0.261252^{*}$ & $-0.056941 * *$ & $-0.385306^{* *}$ & -0.002677 \\
\hline TOBINQ & 0.009625 & $-0.082471 * *$ & 0.004336 & $0.032917 * * *$ & $0.022933 * * *$ \\
\hline Size & -0.005669 & $0.019476^{*}$ & $0.014312 * *$ & $-0.038299 * * *$ & -0.009802 \\
\hline ROA & $0.001461 * *$ & 0.000383 & -0.0000864 & $0.003998 * *$ & $0.002557^{*}$ \\
\hline C & 0.137506 & -0.044135 & $-0.197961^{* *}$ & $0.767065^{* *}$ & 0.0988666 \\
\hline R-squared & 0.691037 & 0.629645 & 0.626821 & 0.595892 & 0.898875 \\
\hline Adjusted R-squared. & 0.684277 & 0.589965 & 0.607952 & 0.552073 & 0.887910 \\
\hline Durbin-Watson stat & 1.727568 & 2.668187 & 2.073750 & 1.845531 & 2.652882 \\
\hline F-statistic & 102.2143 & 15.86775 & 33.22033 & 13.59898 & 81.97411 \\
\hline Prob (F-Statistic) & 0.000000 & 0.00000 & 0.00000 & 0.0000 & 0.00000 \\
\hline
\end{tabular}

Note. $*$, **, and $* * *$ indicates significance at $1 \%, 5 \%$, and $10 \%$ statistical levels respectively. 
Furthermore, highly leveraged firms hold less cash as results show in table 7 which is consistent with pecking order theory that suggests firms issue new debt when investment needs are high and exceed retained earnings, in the other hand, when retained earnings exceed investment requirements, firms repay their debt and save more cash. The free cash flow theory assumes that low leverage firms are less subject to monitoring, allowing for superior managerial discretion as our result may suggest.

Surprisingly, cash holdings increase with payment of dividend which is not consistent with the trade-off theory. In normal times, the set of predictor variables concerning the main characteristics of the Jordanian industrial companies can explain around 68 percentages of the changes in corporate cash holdings.

When comparing regression results for the pre-crisis and during crisis periods, it is obvious that profitability has a negative effect on cash holdings before crisis supporting the trade-off theory since profitability firms have enough cash flows to avoid underinvestment problems (Ozkan \& Ozkan, 2004), while in the crisis time profitability effect became positive and significant supporting the pecking order theory. The size effect was positive before the crisis period supporting the pecking order theory, since large firms perform better than small firms and have more cash; however, the positive relationship begins to disappear during the crisis time which can be attributed to the trade-off theory that suggest large firms can profit from the economies of scale to reduce transaction cost. Firms that pay dividends hold more cash in the pre-crisis period, and this effect changed during the crisis to a negative effect supporting the trade-off theory. The cash flow effect was positive but not statistically significant before the crisis supporting the pecking order theory since firms with higher cash flows tend to hold more cash, while during the crisis time the relationship became negative and insignificant supporting the trade-off theory since firms with high cash flows get benefit from holding less cash to reduce the opportunity cost of investing in liquid assets. The net working capital has a negative significant effect on cash before and during crisis time. The negative relationship indicates that the Jordanian firm use net working capital as substitute for cash. Long term growth measured by Tobins' $Q$ ratio has a positive but not significant effect before the crisis, this effect became more positive and significant during the crisis time supporting the trade off theory, since firms with more investment opportunities should hold higher cash level for precautionary reasons and to avoid losing such opportunities. Capital expenditure effect remains negative and insignificant for all periods except the post crisis period indicating that firms with large investments in fixed assets has no need to hold high level of cash since it can liquidate its assets when liquidity needed.

Comparing the coefficient of the Dividend yield factor for the pre-crisis period (strongly positive) with post crisis period (negative); it is clear that there is a great changes in dividend policy during crisis time.

When comparing results between pre crisis period and the post crisis period we found that, only dividend yield and investment opportunity keep the same effect on cash holdings (positive effect), while the rest of determinant variables opposite their effect on cash holdings as a result of financial crisis. The adjusted R-square value for the model after crisis time was $(0.887910)$ compared to $(0.607952)$ before crisis, and the intercept was $(0.098866)$ after crisis compared to $(-0.197961)$ before crisis. We can argue that firm's characteristics factors selected in this study can explain $88.8 \%$ of changes in cash holdings after crisis while the same set of variable can only explain $(60.8 \%)$ of changes in cash holdings before crisis, indicating that there is a positive effect of financial crisis on Jordanian corporate cash holdings.

The regression results for base period and pre crisis period was compared to assess the pattern of change during these period of times the results show that, the coefficient for long term growth of the Jordanian firms measured by Tobins' $Q$ was significantly negative in the base period and became insignificantly positive before the crisis, also the coefficient for profitability changed insignificantly from positive to negative. Other factors keep their effects the same. It can be noticed that, adjusted R-square value for pre-crisis model is higher than the base period model indicating that the firm characteristics factors included in regression model can explain more changes in corporate cash holdings before the crisis time.

It is clear that, change in cash holdings from the pre-crisis period to the post crisis period has different patterns to the changes in cash holdings from the base period to the pre-crisis period.

A possible explanation for small t-statistics of some coefficients in the regression model during the different time periods is that, firm characteristics are not the only important components of asset allocation behavior, there is the unobserved effect of governance characteristics which can't be studies here because of unavailability of data for some periods.

\section{Conclusions}

This paper investigates whether the cash holdings of the Jordanian companies are high after the financial crisis 
compared to before and which theories can explain these cash holdings. The results show that Jordanian firms save more cash in the crisis time than in the normal time which is consistent with relatively greater agency problems during the crisis that foster the accumulation of more cash.

In general, the cash management policy of Jordanian firms was affected by the financial crisis (2007-2009), and Jordanian firms hold more cash during and after the crisis to stay liquid. The increase in cash holdings was driven by increasing debt, decreasing investment activity and reducing payouts to shareholders. Also, change in cash holdings from the pre crisis period to the post crisis period has different patterns to the changes in cash holdings from the base period to the pre crisis period.

Moreover, in normal times Jordanian firms follow the trade off theory and pecking order theory to determine the appropriate cash balance they should hold. Also, the results can tell that; in bad times the Jordanian firms became more conservative and hold more cash for precautionary purposes.

\section{Acknowledgments}

The author is grateful to the Applied Science Private University, Amman, Jordan, for the full financial support granted to this research project (Grant No: DRGS-2014-2015-27).

\section{References}

Afza, T., \& Adnan, S. M. (2007). Determinants of corporate cash holdings: A case study of Pakistan (pp. 164-165). Proceedings of Singapore Economic Review Conference (SERC) 2007, August 01-04, Organized by Singapore Economics Review and the University of Manchester (Brooks World Poverty Institute), Singapore.

Al-Amarneh, A. (2013). Why do Jordanian firms hold cash? An empirical examination of the industrial companies listed in ASE. International Journal of Academic Research, 5(1), 103-111. http://dx.doi.org/10.7813/2075-4124.2013/5-1/B.18

Almeida, H., Campello, M., \& Weisbach, M. S. (2004). The cash flow sensitivity of cash. Journal of Finance, 59, 1777-1804. http://dx.doi.org/10.1111/j.1540-6261.2004.00679.x

Baumol, W. J. (1952). The transactions demand for cash: an inventory theoretic approach. Quarterly Journal of Economics, 66(4), 545-556.http://dx.doi.org/10.2307/1882104

Besley, S., \& Brigham, E. F. (2005). Essential of managerial finance (13th ed.). Thomson, South-Western.

Campello, M., Giambona, E., Graham, J. R., \& Harvey, C. R. (2011). Liquidity management and corporate investment during a financial crisis. Review of Financial Studies, 24(6), 1944-1979. http://dx.doi.org/10.1093/rfs/hhq131

Cossin, D., \& Hricko, T. (2004). The benefits of holding cash: A real options approach. Managerial Finance, 30(5), 29-43. http://dx.doi.org/10.1108/03074350410769056

Duchin, R., Ozbas, O., \& Sensoy, B. (2009). Costly external finance, corporate investment, and the subprime mortgage credit crisis. Journal of Financial Economics, forthcoming.

Elkinawy, S., \& Stater, M. (2007). Cash holdings and firm value during Latin American financial crises. Retrieved

from http://www.fma.org/Orlando/Papers/Cash_Holdings_and_Firm_Value_in_Latin_America.pdf

Gao, P., \& Yun, H. (2009). Commercial paper, lines of credit, and the real effects of the financial crisis of 2008: Firm-level evidence from the manufacturing industry. Retrieved from http://ssrn.com/abstract $=1421908$

Jensen, M. (1986). Agency costs of free cash flow, corporate finance and takeovers. American Economic Review, $76,323-329$.

Kahle, K. M., \& Stulz, R. M. (2011). Financial policies, investment, and the financial crisis: Impaired credit channel or diminished demand for capital? Fisher College of Business Working Paper, 2011-3. Retrieved from http://papers.ssrn.com/sol3/papers.cfm?abstract_id=1754660>

Keynes, J. M. (1936). The general theory of employment, interest and money. London: McMillan.

Lian, Y., Xu, Y., \& Zhou, K. (2011). How and why do firms adjust their cash holdings toward targets? Evidence from China. Frontiers of Business Research in China, forthcoming.

Meltzer, A. H. (1963). The demand for money: A cross-section study of business firms. Quarterly Journal of Economics, 405-422. http://dx.doi.org/10.2307/1879569 
Miller, M. H., \& Orr, D. (1966). A model of demand for money by firms. Quarterly Journal of Economics, 80, 413-435. http://dx.doi.org/10.2307/1880728

Myers, S. C., \& Majluf, N. S. (1984). Corporate financing and investment decisions when firms have information that investors do not have. Journal of Financial Economics, 13, 187-221. http://dx.doi.org/10.1016/0304-405X(84)90023-0

Opler, T., Pinkowitz, L., Stulz, R., \& Williamson, R. (1999). The determinants and implications of corporate cash holdings. Journal of Financial Economics, 52, 3-46. http://dx.doi.org/10.1016/S0304-405X(99)00003-3

Ozkan, A., \& Ozkan, N. (2004). Corporate cash holdings: An empirical investigation of UK companies. Journal of Banking and Finance, 28(9), 2103-2134. http://dx.doi.org/10.1016/j.jbankfin.2003.08.003

Pinkowitz, L., Stulz, R., \& Williamson, R. (2013). Is there a U.S high cash holdings puzzle after the financial crisis? Dice Center WP 2013-7. Fisher College of Business WP 2013-03-07. Retrieved from http://ssrn.com/abstract=2253943

Song, K., \& Lee, Y. (2012). Long-term effects of financial crisis: Evidence from cash holdings of East Asian firms. Journal of Financial and Quantitative Analysis, 47(3), 617-641. http://dx.doi.org/10.1017/S0022109012000142

White, H. (1980). A heteroskedasticity-constant covariance matrix estimator and a direct test for heteroskedasticity. Econometric, 48(4), 817-838. http://dx.doi.org/10.2307/1912934

\section{Copyrights}

Copyright for this article is retained by the author(s), with first publication rights granted to the journal.

This is an open-access article distributed under the terms and conditions of the Creative Commons Attribution license (http://creativecommons.org/licenses/by/3.0/). 